\title{
THE NARRATIVE ERASURE OF ADAM IN CAIN'S BIRTH IN GEN. 4:1. SOME NOTES ON EVE, SEX, AND VULNERABILITY
}

Gerrie F. Snyman

University of South Africa

\begin{abstract}
The essay explores the different translations of Gen. 4:1 in terms of the use of the

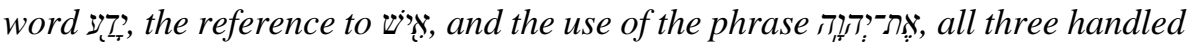
differently in the interpretation in the textual traditions that followed. By all accounts, it seems that conception and birth in Gen. 4 follow the standard formulas, except Eve's proclamation at Cain's birth. Eve proclaims she acquired a man with the help of or from the Lord. Only one translation interprets w as "son"; the rest read it as "man". Adam appears to be a mere sperm donor and is ignored in Eve's proclamation. What should one make of Eve's proclamation at Cain's birth? Is her proclamation a joyous response to motherhood? Alternatively, does she now proclaim a certain distance from Adam, even an invulnerability, emasculating him? In order to find an answer to this question, this essay starts by discussing various translations of the Masoretic text in order to grasp what the general understanding of the text appears to be. It then looks at the word that is used to denote sex, the proclamation of Eve in terms of what is meant by "man", and the role played by the deity in the object clause et Yahweh. The essay concludes that Eve's proclamation of Cain's birth is a joyful claim to motherhood, but an unintended consequence is the narrative erasure of Adam, turning him into a mere sperm donor.
\end{abstract}

Keywords: Cain; Eve; Adam; Knowledge; Sexuality; Vulnerability; Ethical moment; Targums; Genesis Rabbah; The Red Turtle

\section{An unlikely introduction}

The film The Red Turtle (De Wit 2017), ${ }^{1}$ underscores, to my thinking, the issue of vulnerability in general and perpetrators who become vulnerable more specifically. Vulnerability has a positive as well as a negative connotation (Snyman 2017:190-193). Negatively, it refers to harm, injury, and suffering, and renders the subject weak, powerless, and exploited. Positively, vulnerability is regarded as part of the human condition and renders everyone susceptible to the negative effects. But it also makes it possible for human beings to become open towards other people or other things, for example, on an epistemic level, it opens up human beings towards change in overcoming willful ignorance (Gilson 2016:96). Invulnerability stands in contrast to the negative

Mark Kermode (The Guardian 2017) describes it as follows: "[T]his is a film that respects the sound of silence. It is a work of art which transcends boundaries of language, culture, geography and age." For a symbolic interpretation of the film, see David Duprey, "The meaning of the Red Turtle: Nature's beautiful chaos" That Moment In (blog), 13 February 2017. https://www.thatmomentin.com/red-turtle-meaning/. 
definition of vulnerability: it is regarded as an impediment and limitation which needs to be repudiated or ignored (Snyman 2017:193). Invulnerability flourishes in oppressive social, political, and economic contexts, and cultivates ignorance of vulnerability. Whereas knowledge of vulnerability causes discomfort and unease, invulnerability enables one to construct an impenetrable shield as protection against any harm or injury.

The Red Turtle is an animated feature film of a tall, thin, long-haired man clothed in a torn loincloth, shipwrecked on an island. He is evidently vulnerable in a negative way, harmed by the storm and injured during the ordeal. The viewer is invited to share in his vulnerability, when the marooned man starts to build a raft on which he intends to escape from the island. However, a red turtle obstructs his endeavors. The red turtle demolishes the raft every time it reaches a certain distance from the island, turning the encounter into a metaphor for the human being against nature. The viewer does not know why the turtle prevents the man from leaving. All one sees is the pent-up frustration, anger, and eventual wrath of the man after his last try. He ferociously attacks the turtle on the beach, leaving it on its back to die. Upon the turtle's death, it turns into a beautiful woman with whom the man has sex and she gives birth to a child.

He must have known her. Once. The couple has only one child while living on the island and growing old. The film reminds me of the pseudepigraphic story, The life of Adam and Eve (R. H. Charles 1913), where they have 30 sons and 30 daughters. In the biblical narrative, however, Adam and Eve end up with one child, Seth, because Cain had to leave the tribe as he violated morality by killing his brother Abel. Signe Baumane (2016) asks the film the following question:

One would realistically expect that a man and a woman living on a deserted island without contraceptives would have at least 12 - 16 offspring. "Did they have sex only once?" - I couldn't help but ponder. "Or is he pulling out?"

Jim Harper (2017) connects the film to creation mythology, "with Eve arising from the red turtle's shell and giving birth to a son, creating a trinity". Whereas Baumane sees an aspiring couple motif in the story, Harper sees in it "the man's unconscious desire to create". The man wants to leave the island, but the red turtle prevents him by tormenting him, and then delivers him by giving birth to a son. Baumane argues that here the film becomes somewhat of a cliché with the son growing up and the parents getting older, slipping into old age. The man dies, after which the mother turns back into a red turtle and slips back into the see. Baumane sees this as a comment on womanhood:

[W]omanhood is an eternal, mysterious force that outlives men. [...] Women are mythical creatures - animals that are able to briefly become human. I am sorry to say that in 2016 such views/metaphors don't do any good to us, women trying to achieve equal place in society. Women are human 24 hours every day of our lives, and, just like men, we feel pain and can die and be killed. Idolizing womanhood is just as belittling as judging women on their looks. (Baumann 2016: n.p.)

Eve's exclamation at the birth of her oldest son is similarly a comment on womanhood, as if she found redemption in bearing children (1 Tim. 2:15). Baumane's caution against culturally induced prejudices about women, is likewise valid for current readers' 
perspective on Eve, who carries the blame in the Bible for being subordinated to men, and stereotyped with all sorts of weaknesses. Eve's exclamation is in glaring contrast to the silence of the characters in The Red Turtle. In fact, there is no deity in the film, whereas Cain's birth is attributed directly to Yahweh. The man, woman, and boy remain nameless over-against the deliberate naming in the creation story and Cain's birth.

However, both Eve and the woman in the film are created from something unconscious: Eve from a sleeping Adam and the woman from a dead red turtle killed by her future partner. After the story of Cain, Adam and Eve disappear from the scene, and when the son of the shipwrecked man and red turtle woman comes of age, he moves away (swims away with other turtles) to an unknown destiny. This is similar to Cain, who had to leave the place where he grew up, with the difference that Cain bore more guilt and shame than this young man.

To take Harper's suggestion further, in my essay the story functions as a voiceless counterfoil to the story of Cain, especially the exclamation of Eve and the issue of sex and motherhood. All three stories embody physical movement - a journey, a flight, or migration. Adam is expelled and moves to the east of Eden, Cain migrates to the land of Nod because he could no longer live in the midst of his tribe and the presence of Yahweh, the marooned man came from elsewhere and ends up on an island he cannot get away from. In all three stories the final destination is not geographically identified.

All the characters manifest a negative vulnerability: Adam and Eve become vulnerable when they enter life east of Eden with toil and hardship awaiting them. Cain is vulnerable in terms of the favour of the deity who does not accept his sacrifice and he preys on the vulnerability of his brother, killing him. The main character in The Red Turtle equally conveys vulnerability, first negatively in terms of harm and injury, which he endures and causes, and secondly positively, when the dead turtle ironically provides him with a partner, a wife, as a chance to start a new life. Does Eve's proclamation display a positive vulnerability at the birth of Cain, him being the blessing Eve was waiting for? Will it be going too far to ascribe to it an enthusiastic response amidst the birth pangs? Alternatively, does Eve pronounce a certain distance from Adam, even an invulnerability with which she is trying to shield herself from the future acts of Cain? In fact, the Jewish reading tradition does not always view her proclamation in a positive light, as claiming motherhood, but rather in quite a negative way, with the aim of tainting Cain's origins. To whom does "man" refer here, to Adam, her companion, or to Cain, her offending son?

To find an answer to these questions, I start out with various translations of the Masoretic text in order to grasp what the general understanding of the text appears to be. ${ }^{2}$ I will then look at the word that is used to denote sex, the proclamation of Eve in terms of what is meant by "man", and the role played by the deity in the object clause $e t$ Yahweh.

This essay is an edited version of a paper presented at the 2018 Propent-seminar under the auspices of Prof. Jurie le Roux of the University of Pretoria. The audience was made up of Europeans and Africans as well as Euro-Africans. Hence the translations selected reflect most of the languages of the intended audience. 


\section{Translations of Gen. 4:1}

In contrast to the wordless animated film, words about sex in the biblical text create a problem. The text presents three problems: the use of the word and the use of the phrase the textual traditions or translations that followed. In Gen. 4:1 the reader meets Cain after the narrator pronounced a sexual encounter between his father and mother, yet the mother links Yahweh to fatherhood:

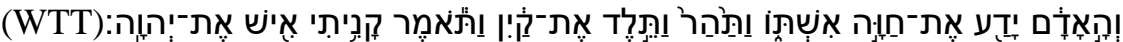

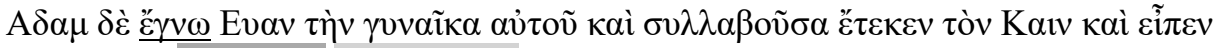

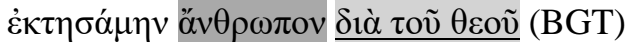

The man had intercourse with his wife Eve, and she conceived and gave birth to Cain. "I have acquired a man with the help of Yahweh," she said. (NJB)

And Adam knew Eve his wife; and she conceived, and bare Cain, and said, I have gotten a man from the LORD. (KJV)

Adam connut Ève, sa femme; elle conçut, et enfanta Caïn et elle dit: J'ai formé un homme avec l'aide de l'Éternel. (LSG)

L'homme connut Eve sa femme. Elle devint enceinte, enfanta Caïn et dit: «J'ai procréé un homme, avec le SEIGNEUR.» (TOB)

Und Adam erkannte seine Frau Eva, und sie ward schwanger und gebar den Kain und sprach: Ich habe einen Mann gewonnen mithilfe des HERRN. (LUT)

Und der Mensch erkannte Eva, seine Frau, und sie wurde schwanger und gebar Kain, und sie sprach: Ich habe einen Sohn bekommen mit Hilfe des HERRN. (ZUR)

Adama a kena dikobong tsa mosadi wa hae, Eva; mosadi a ithwala, a tswala Kaine. Yaba Eva o re: "Ke fumane monna ka thuso ya Morena" (SO 1989)

Atame o ne a itse Efa, mosadi wa gagwe; ke fa a nna moimana, a belega Kaine a re: "Ke bonye monna ka thuso ya MORENA." (Setswana 1970)

En die mens het sy vrou Eva beken, en sy het swanger geword en Kain gebaar en gesê: Ek het 'n man verkry met die hulp van die HERE. (Afrikaans 1953)

Die mens het met sy vrou Eva gemeenskap gehad, en sy het swanger geword. Sy het vir Kain in die wêreld gebring en uitgeroep: "Ek het 'n man in die wêreld gebring met die hulp van die Here!" (Afrikaans 1983)

Of the translations cited above, the newer translations (NJB 1985; Afrikaans 1983) explicitly refer to sexual intercourse, whereas the more traditional or older translations 
use a euphemistic or general description of "knowing" to denote sexual penetration with the aim of conception. By all accounts, it seems the conception and birth follow the standards formulas, except for Eve's proclamation at the birth. At Cain's birth, Eve proclaims she acquired a man with the help of, or from, the Lord. Only one of the surveyed translations interprets is, to whom does "man" refer, Adam or Cain? Most interpretations understand "man" here as referring to Cain, because of the word play between the name of Cain and the

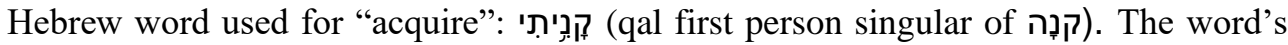
semantic field entails buying someone as a wife, receiving insight, or to produce a progeny (which is the meaning Koehler-Baumgartner (1958) attaches to the verb). But let me first look at the verb "to know".

\section{Knowledge: Adam "knowing" Eve}

$\boldsymbol{\nu}{ }^{\prime}$ ' is a word with several functions, signifying knowledge of some kind. "To know" has cognitive, relational, and (euphemistic) sexual implications as discussed in dictionaries such as Koehler and Baumgartner (1958), Botterweck and Rinngren (1978), and individual word studies such as the one by Schotroff (1978). An important question here, is whether comprehension of the semantic fields of the word throws some light on the issue of vulnerability. I refer to the issue of epistemic vulnerability which makes knowledge possible and reduces ignorance. Gilson argues as follows (2016:96): "[I]t seems reasonable to propose that epistemic vulnerability is vital for all; we all have lapses, gaps in our experience and attunement that demand alterations in our knowing attitudes, which the cultivation of epistemic vulnerability can ameliorate." Gilson (2016:98-100) sketches five defining aspects of epistemic vulnerability:

(1) An openness to not knowing;

(2) An openness to being wrong, yet being able to embark upon defining one's beliefs, ideas and feelings;

(3) The ability to learn from situations if one experiences the discomfort of not knowing, of being foreign, or of being the uncomfortable party;

(4) An openness to the ambivalence of our emotional and bodily responses and to reflecting on these responses; which may lead to

(5) Immersing oneself in unfamiliar settings that alter one's beliefs, ideas, the self, and the sense of one's self.

Schottroff's (1978:682-701) explanation corresponds with that of Koehler and Baumgartner, by relating knowing primarily to observation through the senses, especially through the eyes and ears, which engage objects and facts of one's world through experience and meeting with others. Of importance here, is Schottroff's (1978:689) differentiation between an ethical ability to distinguish between good and evil, and an autonomous decision based on a particular life-orientation or sexual experience (lust and passion). The ethical ability opens the door for a discussion on vulnerability in the way knowledge is generated.

Botterweck (1986:448-81) acknowledges the complexity of a variety of epistemic processes expressed by the various verbs in the semantic field. He discerns between secular, religious, and revelational knowledge, which I would link to the differentiation 
of body, mind, and soul. Secular knowledge is cognitive, that is, knowledge obtained with sensory and visual experience of the body. Then he argues that the one with knowledge, is the one with the physical ability to apprehend with the eyes and the heart, i.e. the mind. The heart is the organ of perception and knowledge and the seat of memory (Botterweck 1986:463): "In the heart, the various objects of perception become concentrated to form insight into the true nature of the world, on the basis of which people may consciously frame their lives." With regard to knowledge of good and evil (the mind), he refers to the ability to make a moral distinction between good and evil as a way to secure the power for oneself to live autonomously, i.e. to be like God. Sexual knowledge and experience, that is, knowledge of how to procreate, beget and bear children, knowledge of joy and suffering, life and death, are forbidden, because it makes human beings like God (revelational).

Epistemic vulnerability stands in contrast to the distinction of knowledge in terms of mind, body, and soul. Epistemic vulnerability relates to the affective and bodily dimensions of knowledge, usually ascribed to these more profound types of knowledge. What these more profound types of knowledge fail to achieve, is to link the corporeal with the effect or the emotional, in other words, a more holistic picture of knowledge, knowledge that has been integrated so as to change habits. Epistemic vulnerability not only relates to observing via the senses and the achievement of certain technical skills, but it starts with the realisation that one does not have certain skills in the first place, and needs to evolve in order to obtain those skills that are lacking. The realisation that one lacks specific skills, is basic self-knowledge, but also involves the courage to venture a step into the unknown, i.e. to interact with other people despite becoming uncomfortable. As Gilson (2016:114) puts it succinctly, "epistemic vulnerability entails rejecting the closure of the self that defines invulnerability. Instead, one begins to comprehend oneself as a being who has come into being and is continually evolving, one positions oneself as one who has been and will continue to be affected by others." It is an effort not to fall into the trap of knowing ignorance. Epistemic vulnerability not only implies the possibility of a change in belief systems, but a change with regard to what one does, and how one thinks and defines oneself (Gilson 2016:113).

Koehler and Baumgartner (1958), Botterweck (1986), and Schotroff (1978) look at knowledge from a different epistemology. Their epistemology enables them to distinguish a duality between the mind and the body, although there are notes of vulnerability that shine through when they refer to experiencing and learning as personally caring for or knowing someone. Thus, I would suggest that getting to know someone personally, as well as caring and observation by experience, bring into play sex through intercourse and the issue of vulnerability in general, although the latter is not stated explicitly. Whereas Levinas (1985) implies the ethical moment in metaphorical terms of nakedness and destituteness, knowing as a euphemism for sexual intercourse implies physical nakedness, a real vulnerability in being stripped of clothing.

In his book on Cain and Abel in the Jewish and Christian traditions, Byron (2011:12) wryly remarks that the description of the first sex scene is "somewhat prosaic" when compared to Abraham's sexual intercourse with Hagar, described as entering into her (Gen. 16:4), as well as Jacob's entering into Leah, Rachel, and Bilhah. However, Rachi (1976:25; cf Halperin 1963:152) believes Gen. 4:1 is not really the first sexual interaction between Adam and Eve. Sex occurred before the fall. Rachi (1976:25) even argues that 
The Narrative Erasure of Adam in Cain's Birth in Gen. 4:1. Notes on Eve, Sex, and Vulnerability 7 the conception of Cain and the subsequent pregnancy of Eve occurred before the deity

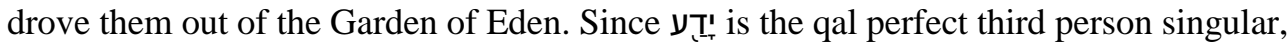
Rachi is of the opinion that the verbs that follow with the waw-consecutive are the imperfectum, turning the verb in perfect into a plu(squam)perfectum, thus placing the events described at an earlier time - that is, when they were still inhabiting the Garden of Eden (cf. Rachi 1976:25).

In other words, the reader needs to bring into play the first three chapters of Genesis. But does it then follow that the first part of the verse, "And Adam knew Eve his wife; and she conceived, and bare Cain", implies that Adam is the subject of Eve's proclamation? In the first part the subject comes before the predicate, emphasising the subject, in this case Adam, telling us what happened to Adam in the meantime. Gen. 3 ends with the angels guarding the entrance to the garden, and in Gen. 4 the reader is referred back to Adam, at this stage having been driven out of the garden. What was he up to? Well, he was having sex with Eve, or, at least, he started to get to know better the woman the deity gave him as a companion. One can argue that Adam is fronted (see below).

Cassuto ([1961]1972:197) formulates the relation between Gen. 4 and Gen. 2-3 as follows: "[W]e are told here that the promise given to Eve that she would bear children in order that the human species might survive even after their expulsion from the garden of Eden and removal from the vicinity of the tree of life ( ...) was actually fulfilled." Andre Wénin's essay (1999) develops some of these textual similarities between Gen. 3 and Gen. 4 with regard to the reaction of Cain, and that of Adam and Eve (cf. Vogels 1996; Snyman 2016). Wénin (1999:6) seems to follow Rachi's analysis of the verb in asking critical questions about the pluperfect that puts the "knowing" in the past. Wénin (1999:6) asks the question where in the previous episode it is reported that the first human knows Eve. He suggests that the author could have used other words to denote a sexual interaction, but he thinks the narrator deliberately used "to know" for its plurality of meaning. In Gen. 3:20 the man named the woman Eve, "the living one", or "the one who makes living". The reader gains the impression that Adam knows something about Eve, at least that she is fit for the purpose for which she was made. Earlier, in Gen. 2:23, when the man describes the woman, one also gets from him a sense of knowing: "This at last is bone of my bones and flesh of my flesh. This one shall be called Woman, for out of Man this one was taken." In Gen. 4:1, the wife becomes the object of his knowing - Adam knows Eve. Of the 950 uses of the word, only a few instances refer to sexual intercourse, of which a small number are not idyllic. Wénin (1999:10) argues the author could have used other words, but they do not suggest a relationship of power as According to him, Adam knowing Eve entails exerting his power over her, because not only has she been created from his body, but also based on the nature of the difference between.

To know someone (hetero)sexually, as discussed above, implies a certain measure of vulnerability in being naked and being penetrated or penetrating, sharing in a common vulnerability (Gilson 2016:88). If such a common vulnerability is not recognised or shared, but disavowed between the two engaging partners, the sexual act opens up the possibility for aggressiveness, resulting in abuse of the vulnerability of one of the partners. Of Adam it is said that he knows Eve, his wife, with a possessive suffix. She is 
an object to be owned, and her function in the story is not her femininity, but her maternal role (Wénin 1999:9). Both appear invulnerable.

Cain originates from a man who exercised power over his wife, a typical situation within patriarchal society. Gilson (2016:88) claims that the disavowal of someone else's vulnerability perpetuates social oppression. Reading the text in this way, takes the focus away from the vulnerability during the sexual act, and focuses on the result as an exercise of power. How, then, should Eve's proclamation be interpreted? Does she affirm her maternal role, or does she take revenge on her companion's exercise of power when she links the deity to the birth of her first-born?

\section{Eve's proclamation at birth}

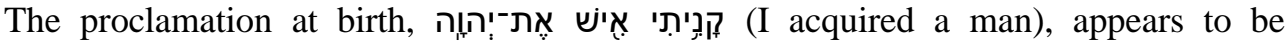
complicated: Did Eve acquire a man (like a possession - turning the tables in the power relationship), or did she procreate a man (by giving birth to a boy)? The word used for "to acquire", קִגִנִיתִ, does not really translate into to produce children or procreate, although that meaning is found in some of the translations.

Schmidt (1978:650-659) makes a strong case that the word cannot mean "to (pro)create". He thinks that is a wild guess. In terms of "create", the verb is only used in connection with the deity (Ex. 15:16; Ps. 74:2). Says Schmidt:

Scheinen die Verbindung mit Gen 2-3 sowie die Situation der Geburt für die Gleichung qnh = "schaffen" zu sprechen, so gerät diese Auffassung jedoch sachlich in Schwierigkeit, weil ein Entsprechungsverhältnis von göttlichem und menschlichem Handeln im Zusammenhang sonst nicht zum Ausdruck kommt, also auch kaum intendiert ist. (Schmidt 1978:658)

To have a woman utter the words "to create", with "man" as the object, does not sound in any way plausible. The two French translations, however, use the word in that sense, but the other translations use it in a sense of having received someone, or acquired someone, with whom there would be a strong relationship, like a possession. The translation used by Rachi (1976:25) in his commentary on Genesis, refers to an association with the deity in that the latter is the creator of both: "Lorsque Dieu $m$ 'a créé ainsi que mon mari, il était seul à nous créér. Mais pour cet enfant, nous sommes associés avec Lui."

Lipinski (2004:58-65) also rejects the meaning "to create", because the prevalence in the Hebrew Bible is the meaning "to acquire possessions, monetary payments or wisdom". Nevertheless, he does not deny that the root meaning may refer to to beget or to bear a child, but this meaning is only attested to in South Arabian, Ugaritic, and Amorite. Lipinski relates to Cassuto's argument by linking Eve's words to the original mother goddess:

Here the biblical redactor may have employed a statement originally uttered by a mother goddess, comparable to a passage in the Chaldean cosmogony that describes Aruru as creating the human race with Marduk: "With him Aruru created the seed of humanity." This must not be taken to mean that humanity issues from the (sexual) 
The Narrative Erasure of Adam in Cain's Birth in Gen. 4:1. Notes on Eve, Sex, and Vulnerability 9 union of the god and goddess: Aruru forms a human figure from clay, and Marduk breathes life into its soul. (Lipinski 2004:61)

Ellen van Wolde (1991:25-41) strongly disagrees with Schmidt's argument. She centres her argument on the words קנה and איש איש in terms of Gen. 2-3, claiming that every man is brought forth by אישהה, except the first one who was brought forth by אדמה with Yahweh. To her then, אדמה brings forth an אימה together with Yahweh, and אישה brings forth anether with Yahweh. Hence, in Gen. 4, Eve gives birth to an איש. Eve's exclamation merely explains Cain's name, whereby he is defined as a creature formed by Eve and Yahweh:

It would seem to me that קנה can be understood both in relation to Genesis 2-3 and in relation to the other elements of $4.1 \mathrm{~b} ß$. What has been indicated in Genesis 2-3 as an "ability" or "capacity" is realized in Gen. 4.1. The ability to bring forth children is transformed into actually bringing forth children. This connection furthermore functions in an individual way within 4.lb itself. In the construction indicates the sociative, to be translated as "together with" (cf. Cassuto 1972:198 [“equally with"]; Westermann 1976:397 [“mit”]). Eve achieves something together with YHWH, which is indicated by the word קנה and relates the birth of her son with the name קין. Schmidt's argument, that it is impossible for קנה here to mean "to bring forth" or "to create" because these meanings occur only in connection with God, is invalid. Here the word definitely refers to creation as the activity of God, and in particular to the coherence between the creation of God and the procreation of woman. The connection between Eve's giving birth and YHWH

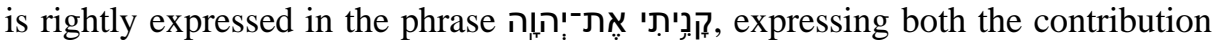
of woman, Eve, and the contribution of YHWH to the bringing forth of life by human beings. (Van Wolde 1991:27-28)

In other words, the deity provides Cain with life in conjunction with the mother, Eve, alluding to a relationship between Cain and the deity. Van Wolde bases her argument on

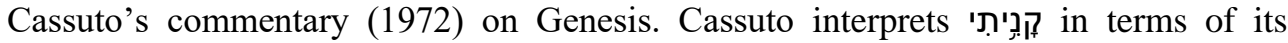
Canaanite roots, the latter referring to form or to give birth to someone. He relates these roots to various Ugaritic inscriptions, especially those referring to Ashera as the mother of gods. Ashera as the mother of gods signifies that she gave birth to gods (Cassuto 1972:200). Cassuto finds further support in Ps. 139:13 and Prov. 8:22. Lipinksi (1978:61) adds Deut. 32:6, arguing that the word was most probably "the original and primary meaning of the root in the ancient Canaanite tongue", and that it developed later to mean "to acquire". The deity is likened to a father who begets Israel. Moreover, the personal name El-kana (elqana) alludes to divine involvement in the conception of a child. Eve's proclamation is viewed as poetic diction, of which Cassuto (1972:201) says: "In poetic diction, which naturally tends to preserve the archaic elements of a language, the full original signification of the root was also retained, especially in connection with two concepts: Divine creation and parental procreation." Subsequently, Cassuto (1972:201) interprets Eve's exclamation as follows: "[T] giving birth to her first son (my emphasis - GFS), boasts of her generative power, which approximates in her estimation to the Divine creative power." In other words, the deity 
formed the first man and Eve formed the second man, implying that Eve has equal standing to the deity in the rank of creators, even to the point of feeling a personal nearness to the Divine Presence itself. When one follows Cassuto's argument, Eve's proclamation is understood more in the sense of the joy of motherhood over the birth of her first-born, than as revenge on the power of her companion. But then the proclamation may have an unintended consequence: Adam, the biological father, is out of the picture, hence his possible emasculation, or rather weakening of his power.

However, Van der Merwe and Naudé (2017:530) refer to the notion of fronting: "If the preverbial field (i.e. part of the clause that precedes the verb) is occupied by a constituent, this phenomenon is referred to as fronting of that constituent." Fronting indicates that a specific event or entity is the focus of an utterance. The identity of that event or entity is found in what precedes, or what is then fronted (Van der Merwe and Naudé 2017:502). Adam is mentioned with reference to knowing Eve, and it could be that Adam is the name fronted by the word "man". ${ }^{3}$

\section{Adam's weakening of power: narrative erasure}

According to Wénin (1999:7), Eve focuses on Cain, and Adam's role diminishes or disappears until Gen. 5. His disappearance from the scene after the sexual act makes one wonder whether he is emasculated. With emasculation is meant the weakening of male power. He only reappears to become another sperm donor for Seth's birth, whereas in the rabbinical tradition he receives a bigger role (Snyman 2016). Wénin (1999:7) reads more into Adam's disappearance, relating his argument to Gen. 2:17, namely the prohibition to eat from the tree of knowledge of good and evil. This prohibition, he argues, indicates a relation between being human, and the misfortune and nuisance of not knowing everything. The inability of the man and the woman to know each other fully, places a severe strain on their relationship.

If Wénin is right, one has to ask, what is the implication of the inability to fully know someone? In terms of power relations, one consequence would be the construction of invulnerability based on an ignorance of vulnerability. Another consequence of the inability to perceive or apprehend vulnerability of the other, would be the presence of social oppression, argues Gilson (2016:88).

The story reduces Adam to his male reproductivity, whereas Eve receives more attention. Wénin (1999:7) sees in Eve a repetition of Adam's modus operandi in which she turns the tables in terms of power relations. She gives her son a name and she talks about herself while making her son the object of her discourse. The effect is that Adam is reduced to a mere sperm donor, while Eve extols the deity to the position of the real partner in the conception of the child (Culbertson 2006:\$28.2). The play between the verb "acquire" and the root of Cain's name becomes important here. Just as Eve became the possession of Adam, Cain seems to become the possession of Eve, according to Wénin (1999:10). Moreover, by calling him a man, Cain may be seen as replacing Adam. He becomes Eve's possession. For this reason, Wénin (1999:10-13), with his use of the word "phagocyte", ascribes the cause of Adam's emasculation to Eve. 
The Narrative Erasure of Adam in Cain's Birth in Gen. 4:1. Notes on Eve, Sex, and Vulnerability 11

In Wénin's mind, then, Adam is finally wiped from the scene as soon as the deity is suggested as the father: ${ }^{4}$

Ainsi, possédée par son homme qui n'a pas vu en elle un sujet, mais un object comblant son manqué, la femme semble imiter celui-ci peut-être en guise de revanche. Elle compense son manqué à être comme femme face à l'humain en prenant possession de l'objet qui la valorise en tant que mère. Et dans le même movement, elle evince l'humain de la relation entre son fils et elle. (Wénin 1999:11)

Culbertson (2006:\$28.5) refers to Adam’s disappearance as narrative erasure in Eve’s response. He (Culbertson 2006:§28.2-3) points to Eve’s “own agency in a self-serving manner", reflecting back to herself an idealised image of importance, desirability, control, and perfection. Cain becomes an extension of herself (Culbertson 2006:\$28.3), both narcissistic.

The erasure of Adam is not strange to the stories of the patriarchs in Gen. 1-11. Howard Eilberg-Schwartz (1994), referring to the dilemma of monotheism, finds emasculation in principle embedded within ancient Israel's cult: the masculine deity legitimates authority, deifies masculinity, but renders human masculinity quite unstable. The social system of ancient Israel and its portrayal of masculinity is deeply entrenched in what we today call heteropatriarchy, but the religious system and its divine-human relationship are described in erotic and sexual terms, evoking images of homoeroticism:

But the heterosexual metaphors in the ancient texts belie the nature of the relationship in question: it is human males, not females, who are imagined to have the primary intimate relations with the deity. The Israel that is collectively imagined as a woman is actually constituted by men, men like Moses and the patriarchs. And these men love, in ways that are imagined erotically and sensually, a male deity. (Eilberg-Schwartz 1994:3)

When Eve proclaims that she acquired a man with the help of the deity, she displaces Adam in the relationship with God, creating in the process an unstable masculinity, which Eilberg-Schwartz (1994:3) sees as problematic in acts of procreation. To be a man in ancient Israel, you had to marry and have children, carrying on the lineage of the ancestors. Women were regarded as the natural counterpart of men and men were complementary to women. In ancient Israelite religion, men confronted a male deity, but they were put into the female position in order to become intimate with the deity (Eilberg-Schwartz 1994:137). Men loving a male deity created the need to suppress homoerotic impulses, not only between men but also between men and their male deity. Such suppression resulted in the prohibition of depicting the deity, and in the feminisation or emasculation of men. The masculine deity had men as wives, and Israelite religion preserved heterosexuality to counter the logical consequence of having a relationship with that deity. The masculinity of men was preserved when the deity

4 "Thus, linked to a man who fails to see her as a subject, but rather as an object that fills a need, the woman seems to imitate her husband in an act of revenge. She compensates for her failure to fulfil a need of her man by turning to her child as an object that will value her role as mother. At the same time, she drives out the man from the relationship." [My translation - GFS]. 
turned his back on them, hid his face, or stayed in the clouds (Eilberg-Schwartz 1994:138). The moment men meet the deity, their masculinity becomes unstable and uncertain.

As soon as Eve claims the deity as father, Adam has to disappear from the scene. In fact, the reader only meets him again in Gen. 5. He becomes redundant (EilbergSchwartz 1994:142). Ideally, women would have functioned as a natural partner to the masculine deity. In the cases of Eve, Sara, Rebekah, Leah, Rachel, and Bilhah, the men (their husbands) are superfluous to the births of their children, who are proclaimed to have come from the deity. Moreover, as soon as the deity is imagined as male and heterosexual, women naturally become the object of divine desire. Divine desire necessitates the unmanning of men. The masculine deity affirms masculine power, but masculine power makes human masculinity redundant. This paradox is painfully clear in Eve's acclamation. She proclaims her co-creativity with the deity, while excluding the human input of her male consort.

In contrast, the Jewish reception of the Masoretic text in this regard avoids this problem out of fear of what is believed to be anthropomorphisms (cf. Snyman 2016).

\section{Jewish reception: the Targums and Genesis Rabbah}

\begin{tabular}{|c|c|c|c|}
\hline $\begin{array}{c}\text { Gen. 4:1 MT } \\
\text { NJB }\end{array}$ & Onkelos & $\begin{array}{l}\text { Pseudo- } \\
\text { Jonathan }\end{array}$ & Neofiti \\
\hline $\begin{array}{l}\text { The man had } \\
\text { intercourse with } \\
\text { his wife Eve, and } \\
\text { she conceived and } \\
\text { gave birth to Cain. } \\
\text { "I have acquired a } \\
\text { man with the help } \\
\text { of Yahweh," she } \\
\text { said. }\end{array}$ & \begin{tabular}{l}
\multicolumn{2}{c}{ And Adam } \\
knew Hava his \\
wife, and she \\
conceived and gave \\
birth to Cain, \\
saying: "I have \\
acquired a man (i.e. \\
a male child) before \\
the Lord."
\end{tabular} & $\begin{array}{l}\text { Adam knew his } \\
\text { wife Eve, who had } \\
\text { conceived from } \\
\text { Sammael, the angel } \\
\text { of the Lord. }\end{array}$ & $\begin{array}{l}\text { And the man } \\
\text { knew Eve his wife } \\
\text { and she conceived } \\
\text { and bore Cain and } \\
\text { she said: "Behold, } \\
\text { I have been given } \\
\text { a son from before } \\
\text { the Lord." }\end{array}$ \\
\hline
\end{tabular}

There is a marked difference in the reception of the text of Gen. 4:1 in the Targums. One of the problems in the Targums is the fear of anthropomorphisms (Le Déaut 1961:2848). Thus, in Targum Onkelos the et JHWH is rendered as מן קדם ה (from before the Lord). It cannot be rendered as "with the Lord", as this is thought to be too anthropomorphic, says Aberbach and Grossfeld (1982:40). Targum Onkelos is straightforward about the sexual intimacy between Adam and Eve, whereas Targum Neofiti merely implies sexual intercourse. Both seek to bypass the underlying anthropomorphism of et Yahweh, by changing the Hebrew text to "(from) before the Lord" (McNamara 1992:64).

Targum Pseudo-Jonathan $(\mathrm{PJ})$ provides quite a different interpretation of the verse. Firstly, it suggests cognitive knowledge of a sexual nature. It reads the verse as follows: "Adam knew that his wife had conceived from Sammael, the angel of the Lord." In other words, Adam knew that Cain was not his child but that of an angel. Another version of Pseudo-Jonathan (Editio Principes of the PJ in Venice [1598]) contains the following 
The Narrative Erasure of Adam in Cain's Birth in Gen. 4:1. Notes on Eve, Sex, and Vulnerability 13 version: "Adam knew Eve his wife, who desired the angel, and she conceived and bore Cain. And she said: 'I have acquired a man, the angel of the Lord."' The perception of Sammael as Cain's father is based on Gen. 5:3, which states that Seth was born in the image of his father. Nowhere is it stated that Cain was born in the image of his father. The conclusion drawn is that he is not Adam's son. The Targum states in 5:3, after the mention of Seth's birth, the following:

When Adam lived a hundred and thirty years, he begot Seth, who resembled his image and likeness. For before that, Eve had borne Cain, who was not from him and who did not resemble him. Abel was killed by Cain, and Cain was banished, and his descendants are not recorded in the book of the genealogy of Adam. But afterwards he begat one who resembled him and he called his name Seth. (Maher 1992:56)

Other Jewish traditions also allude to Sammael, or a serpent, or both. The Babylonian Talmud Shabbath 146a (738), Yebamoth 103b (711) and Abodah Zarah 22b (114) say that Eve copulated with the serpent who infused her with lust, but do not state that Cain is the result of this copulation. One tradition that links Cain to Sammael, is Pirqe de Rabbi Eliezer 21, which states that Sammael went to Eve riding a serpent and she conceived. That it was indeed Sammael, is based on PRE 13, where one reads of Sammael mounting the serpent (Friedlander 1956:92, 150). Targum Pseudo-Jonathan seems to be the earliest text that identifies Sammael as the father of Cain.

In Genesis Rabbah, Adam is linked to the conception and birth of Cain. The commentary grounds this on the grace of the deity, creating a concentric circle starting with its explanation of v. 1, and ending with its explanation of v. 16. The explanation of v. 1 starts with a citation of Ps. 25:6, encouraging God to remember his compassion and mercy, especially towards Adam. In this way, Gen. 4 is directly linked to Gen. 3, described by Erzberger as follows:

Im Geschick Kains zeigt sich der Barmherzigkeit ([...]) und Güte ([...]) Gottes, die der Schöpfung Bestand verleihen. Zentral ist der Themenkomplex des Lehrens und Lernens. Wie die Menschheit von Adam die Fähigkeit der Lebensweitergabe lernt, die Leben erst ermöglicht, lernt sie von Kain den Brudermord. Kain wird jedoch zum Lehrer darüber hinaus. Als erster Mörder wird er zum warnenden Beispiel. Als erster Umkehrer wird er zum Mittler einer Gottesbegegnung, die sich Adam im Lobpreis aneignet. (Erzberger 2011:94)

That Adam is able to procreate after having eaten of the fruit from the tree of knowledge of good and evil, is only by the grace of God (Erzberger 2011:68). The use of Ps. 25 addresses what is going to happen in Gen. 4 as well as what happens in Gen. 3, namely the acknowledgement of guilt, a plea for forgiveness, and an act of mercy from the deity.

In its commentary on Gen. 4:1, Genesis Rabbah refers twice to knowledge, and in both instances it is linked to sexual intercourse. Rabbi Joshua b. Nehemiah thinks that Adam's knowing of Eve is the result of God's mercy, and Rabbi Huna and Rabbi Jakob see in Adam's knowing an example for the rest of humanity to have sex, as no sexual intercourse seemed to have taken place before. Another interpretation, quite laconically, 
suggests that Adam knew he had been robbed of his tranquility! In addition, the snake is brought into the discourse and related to sex: Adam knew what the snake did to him, i.e. arousing sexual desire. Adam knew why he was driven out of the garden, and he knew where to get sexual gratification.

With Eve pregnant and giving birth to the first child, Rabbi Eleazar also has a few words to add. He argues that three wonders happened on that day: the first human beings were created, they had sex, and they brought into the world progeny. Erzberger (2011:68) calls this combination of creation, intercourse, and birth "creation dignity". Rabbi Joshua b. Karba adds: Two entered the bed, and seven left it: Cain and his twin sister, and Abel and his two twin sisters. The births of the twin sisters help to solve the issue of where the sons eventually got their wives.

But what does Genesis Rabbah do with the Masoretic text's reference to Cain as a man and not a child, and the object particle linked to Yahweh? It states a few rabbinical arguments. Rabbi Isaac, for example, is quoted as saying that when a woman sees she has children, she knows her husband is now in her possession. Thus, Eve proclaims that she has Adam in her possession, tying him to her. The man referred to in the text is not Cain, but Adam. In the case of the אֶת Erzberger (2011:69) argues that Genesis Rabbah illustrates here one of the rare cases citing and using a rabbinical exegetical rule. The rule is that the particle can have a limiting function, with the result that Eve's proclamation is put in direct relation with creation: Cain is the first child that has been fathered, and the limitation is that it happened in co-operation with the deity. Genesis Rabbah refers to Gen. 1:26, "in our image" or "after our likeness", of which Erzberger (2011:69) says the imago dei in the human being is a humanly mediated "Gottebenbildlichkeit", as stated in the commentary: "In the past, Adam was created from the ground, and Eve from Adam; but henceforth it shall be, In our image, after our likeness (Gen 1,26): neither man without woman nor woman without man, nor both of them without the Shechinah."

\section{Ecce homo vulnerabilis}

What lies behind Adam knowing Eve, procreating a child who would become the archetype of a murderer in Judeo-Christian thinking? The story leaves a gap, but it is read with the reader knowing that Cain is the perpetrator who has no pity in killing Abel. No one holds Cain back when he leaves for the land of Nod, finds a wife whom he knows, and procreates children. In fact, Adam and Eve themselves are driven out and an angel guards the entrance of the Garden of Eden with a sword. They cannot go back. In The Red Turtle, a red turtle prevents the main character from leaving. He too finds a companion with whom he begets a son.

In each instance, the man "knows" the woman. Referring to the act of sex, a particular vulnerability enters the scene, which reminds me of what Levinas suggests about the ethical moment in which vulnerability is revealed. It is the moment that comes into being in the confrontation between two individuals, each challenging the case of the other on the basis of the $6^{\text {th }}$ commandment in Ex. 20:13 and Deut. 5:17: "You shall not kill." The ethical moment is created in the invisible plea to respect the other, who becomes metaphorically naked in the meeting, an orphan, someone without any relations to any other human being. Both partners in this meeting are stripped of everything, uncovered, in short vulnerable, open to penetration. The plea not to kill, confirms a particular radical 
responsibility that exists between the two parties. The ethical moment happens at exactly that moment when one realizes that the face one sees, imposes a radical obligation not to destroy or violate the other. It is important to realize that the meeting creates mutual vulnerability: it is the recognition of the vulnerability of the other, as well as a concomitant vulnerability in the self. It is when one realizes vulnerability in the self, that one can enter into conversation with the vulnerability of the other. The issue of vulnerability is of particular validity related to the concept of sex. The metaphorical nakedness becomes corporeal, two people stripped of all clothing, eventually losing control momentarily at the point of no return, the instance of complete vulnerability.

In the case of Adam and Eve, the reader is shown that Adam acts as the sperm donor for Eve with regard to Cain, no matter how euphemistically or prosaically the term יד is translated. The word used relates to knowledge, covering a relatively wide semantic field. Where would Adam have learnt about sex? Did he see it in nature? Alternatively, was it a joyous discovery with Eve? In the Jewish interpretative history of Cain, the Rabbis thought to lighten his burden by bringing into play the issue of learning and teaching. In Cain's case, there was no example of murder, although a fragment of Genesis Rabbah refers to Cain's observation of two birds fighting. The suggestion is that he received his knowledge of murder from them. Cain learns from the birds, but he becomes the teacher of death (Erzberger 2011:621-22).

Eve's proclamation at his birth in the Masoretic text is a positive claim of motherhood. Of course, Adam is pushed into the background, because he is not the one carrying the baby for nine months. Moreover, in most of the births of the patriarchs' children, the patriarchs are narratively erased, with the children dedicated to the deity as father. Men are emasculated when the deity arrives on the scene. In Cain's case, some traditions put him in direct opposition to the deity. I am not certain whether Adam's emasculation is as sinister as Wénin seems to imply. I am more inclined to follow Van Wolde, Lipinski, and Cassuto in suggesting that Eve celebrates motherhood, with the unintended consequence of the narrative's erasure of Adam. If one follows EilbergSchwartz's argument, erasure constitutes emasculation.

What is clear, is that Eve's joyful claim of motherhood stands in stark contrast with the end of the story with Cain moving to the land of Nod in Gen. 4:16. It is also noticeable that Adam never interacts with Cain in the Masoretic text, except in the interpretative traditions like the Targum Pseudo-Jonathan. It is as if he is redundant. Cain's exploitation in the latter serves to not only turn him into evil, but also to portray his essence as evil, eventually with a father like Sammael, a destructive figure associated with evil in Talmudic texts and Jewish folklore. Cain cannot be worse off. He is not created in the image of Adam, like Seth, but of Sammael.

\section{BIBLIOGRAPHY}

Aberbach, M. and Grossfeld, B. 1982. Targum Onkelos to Genesis. A critical analysis together with an English translation of the text (Based on Sperber's edition). Center for Judaic Studies, University of Denver. New York: Ktav Publishing House. 
Baumane, S. 2016. Comprehending metaphors of 'The Red Turtle'. Online: http://www.signebaumane.com/blog/2016/10/18/my-point-of-view-on-the-redturtle.

Botterweck, G.J. 1986 ' 'עיזָ'. In G.J. Botterweck and H. Rinngren (eds), Theological dictionary of the Old Testament. Green, D.E. (trans.). Grand Rapids: Eerdmans, $448-81$.

Byron, J. 2011. Cain and Abel in text and tradition: Jewish and Christian interpretations of the first sibling rivalry. Themes in Biblical narrative Jewish and Christian traditions vol. 14. Leiden: Brill.

Cassuto, U. [1961]1972. A commentary on the Book of Genesis. Part 1. From Adam to Noah. Genesis 1-6:8. Abrahams, I. (trans.). Reprint 1972. Jerusalem: Magnes Press, Hebrew University.

Charles, R.H. 1913. The Apocrypha and Pseudepigrapha of the Old Testament. Oxford: Carendon Press. Online: https://www.sacred-texts.com/chr/apo /adamnev.htm.

Culbertson, P. 2006. De-demonising Cain ... and wondering why?, The Bible and Critical Theory 2(3):28.1-28.11.

De Wit, M.D. 2017. The Red Turtle. Animation. Studio Ghibli.

Eilberg-Schwartz, H. 1994. God's phallus and other problems for men and monotheism. Boston: Farrar, Straus \& Giroux.

Erzberger, J. 2011. Kain, Abel und Israel: Die Rezeption von Gen 4,1-16. Rabbinischen Midraschim. Beiträge zur Wissenschaft vom Alten und Neuen Testament 12. Stuttgart: Kohlhammer.

Friedlander, G. 1965. Pirke de Rabbi Eliezer. (The Chapters of Rabbi Eliezer the Great) according to the text of the manuscript belonging to Abraham Epstein of Vienna. New York: Hermon Press.

Gilson, E. 2016. The ethics of vulnerability. A feminist analysis of social life and practice. Routledge studies in ethics and moral theory 26. London: Routledge.

Halperin, H. 1963. Rashi and the Christian scholars. Pittsburgh: University of Pittsburgh Press.

Harper, J.W. 2017. How to interpret the Red Turtle, Notes from a Fish, January 31. Online: https://harperfish.wordpress.com/2017/01/31/how-to-interpret-the-redturtle/.

Kermode, M. 2017. The Red Turtle review - Rapturous minimalism from Studio Ghibli, The Guardian. 2017, 28 May edition. Online: https://www.theguardian.com/film/2017/may/28/the-red-turtle-reviewstudio-ghibli-masterpiece.

Koehler, L. and Baumgartner, W. (eds). 1958. ' 'ידָיָ'. Lexicon in Veteris Testamenti Libros. Leiden: Brill, 365.

Le Déaut, R. 1961. Traditions Targumiques dans le Corpus Paulinien? Semitica 42(1): $28-48$.

Duprey, D. 2017. The meaning of the Red Turtle: Nature's beautiful chaos, That Moment In (blog), 13 February 2017. Online: https://www.thatmomentin.com/redturtle-meaning/.

Levinas, E. 1985. Ethics and infinity: Conversations with Philippe Nemo. Cohen, R. (trans.). Pittsburgh: Duquesne University Press. 
Lipinski, E. 2004. 'קנה'. In G.J. Botterweck, H. Rinngren and H-J. Fabry (eds), Theological dictionary of the Old Testament, xiii. Green, D.E. (trans.). Grand Rapids: Eerdmans, 58-65.

Maher, M. 1992. Targum Pseudo-Jonathan: Genesis. Translated, with introduction and notes vol. $1 \mathrm{~b}$. The Aramiac Bible. Edinburgh: T \& T Clark.

McNamara, M. 1992. Targum Neofiti 1: Genesis. Translated, with apparatus and notes vol. 1A. The Aramaic Bible. Edinburgh: T \& T Clark.

Rachi. S.A. Bereshit. La Genese. Commentaire de Rachi Traduit par M. Le Grand Rabbin Salzer. Paris: Conference on Jewish Material Claims. - La Genese. Commentaire de Rachi. 1976. Le Grand, R.S. (trans.) vol. 1.5. Le Pentateuque en Cinq Volumes Suivis des Haphterot avec Targum Onqelos. Paris: Fondation Samuel et Odette Levy.

Schmidt, W.H. 1978. קָָָָהerben. In E. Jenni and C. Westermann (eds), Theologisches handwörterbuch zum Alten Testament band II. München: Chr. Kaiser Verlag, 650-59.

Schottroff, W. 1978. 'ידָּ Erkennen. In E. Jenni and C. Westermann (eds), Theologisches handwörterbuch zum Alten Testament, band I. München: Chr. Kaiser Verlag, 682-701.

Snyman, G.F. 2002. Rhetoric and ethics: Looking at the marks of our reading/speaking in society, Communicatio 28(1):39-48. Online: http://dx.doi.org/10.1080/02500160208537956. . 2016. Cain and vulnerability: The reception of Cain in Genesis Rabbah 22 and Targum Onkelos, Targum Neofiti and Targum Pseudo-Jonathan, Old Testament Essays 29(3):601-32. Online: http://dx.doi.org/10.17159/23123621/2016/v29n3a14. . 2017. Read as/with the perpetrator: Manasseh's vulnerability in 2 Kings 21:118 and 2 Chronicles 33:1-20, Scriptura 116(2):188-2077. Online: https://doi.org/10.7833/116-2-1318.

Van der Merwe, C. and Naudé, J.A. 2017. A Biblical Hebrew reference grammar. London: Bloomsbury Publishing.

Van Wolde, E. 1991. The story of Cain and Abel: A narrative study, Journal for the Study of the Old Testament 52:25-41.

Vogels, W. 1996. The power struggle between man and woman (Gen 3, 16b), Biblica 77(2):197-209.

Wénin, A. 1999. Adam et Eve: La Jalousie de Caïn, «semence» Du Serpent. Un Aspect du Récit Mythique de Genèse 1-4, Revue Des Sciences Religieuses 73(1):3-16.

Westermann, C. 1976. Genesis. Neukirchen: Neukirchener Verlag. 